\title{
Atmosphere may rise to the top of the West German agenda
}

\section{Munich}

AN impassioned parliamentary report concerning man-made climate change, reduction of stratospheric ozone and rainforest destruction has shattered the stillness that usually descends on Bonn in summer. Political repercussions are expected when the West German parliament returns in the autumn.

The report, written by Bundestag (parliament) member Bernd Schmidbauer (Christian Democrat), offers a preliminary glimpse of the contents of a forthcoming interim report of the Bundestag's Enquete Commission Precautions for the protection of the Earth's atmosphere, of which Schmidbauer is chairman. The commission's full report, to be released in the autumn, will include recommenda-

\section{Lords urge strict measures for $\mathrm{CFCs}$}

\section{London}

THE House of Lords has called for measures to halt the destruction of the ozone layer which are more stringent than those of the Montreal Protocol. The Lords Select Committee on the European Communities recommends, in a report published last week, restrictions on production and consumption of chlorofluorocarbons (CFCs) that would reduce emissions of CFCs by 85 per cent. The committee says that the Montreal Protocol, which will halve production, is an "important milestone in environmental policy" and urges member states of the Community to ratify it. But, on the basis of the conclusions of a review group on stratospheric ozone, the committee says the reductions of CFC emissions in line with the protocol will not prevent further depletion of the ozone layer. And it urges that the Community amends it. Even a reduction of 85 per cent would only stabilize chlorine in the stratosphere; if the atmosphere is to recover, then production of CFCs must be phased out completely, it says.

It also demands an immediate ban on the use of CFCs in non-essential aerosols, a step already taken in the United States and other countries. And it calls for an amendment to the protocol to prevent export of aerosols to countries not party to it. At present, this is "a hole in the Protocol as big as the hole in the ozone layer", says the committee's chairman, Lord Cranbrook. The committee recommends that the government reviews its support for research into the ozone layer and says the development of substitutes for CFCs and halons must be speeded up. Christine McGourty tions for government action. Sources in the Bundestag expect parliamentary action to follow although the commission will continue meeting until 1990.

In his preliminary report, Schmidbauer calls West German attention to some predictions that the Earth's surface temperature will rise $3-9{ }^{\circ} \mathrm{C}$ within a century if the emission of carbon dioxide, chlorofluorocarbons (CFCs) and other 'greenhouse gases' is not reduced.

West Germany is responsible for just 4 per cent (and Western Europe overall 15 per cent) of the worldwide carbon dioxide production of roughly 20,000 million

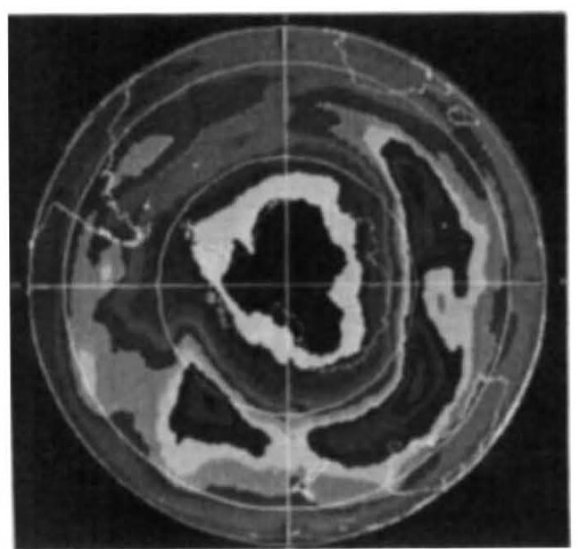

The springtime ozone hole in the Southern Hemisphere on 5 October 1987. See also the story on the left. (Photo: Scientific American.)

tonnes. The United States produces about 25 per cent and the Soviet Union and the Soviet bloc 22 per cent. Schmidbauer argues that West Germany should lead a drive to try to reduce world emissions.

Schmidbauer, echoing the West German Environment Ministry, calls for stricter international guidelines on $\mathrm{CFC}$ release both because CFCs add to the greenhouse effect and because they are implicated in the depletion of stratospheric ozone. Schmidbauer and the Environment Ministry call for a reduction of 85-95 per cent in current levels of CFC production by 2000 .

West German industry produced 112,000 tonnes of CFCs in 1986, more than 10 per cent of the world total. Thirty-five countries pledged at Montreal in September 1987 to reduce CFC output by 50 per cent by 1999 . Neither the Montreal protocol nor its predecessor, the Vienna protocol of 1987, has been ratified by West Germany, although both are on the parliamentary agenda in the autumn. A ministry spokesman said that persuading industry to accept huge production cuts would be "the least of our problems" compared with achieving an international agreement for further reductions in $\mathrm{CFC}$ production beyond the Montreal limits.
Congress investigates 'six-pack rings'

\section{Washington}

THE plastic 'six-pack ring' found itself the unlikely subject of a hearing by the US House of Representatives Committee on Merchant Marine and Fisheries last week. The ring might seem too humble an item for congressional scrutiny, even though it does hold together an important American institution - the pack of six cans of drink that are vital to the enjoyment of a summer's day at the beach. But to the wildlife experts who testified at the hearing, the ring is more than just an ordinary piece of plastic.

In order to grip the cans firmly by their rims, six-pack rings have to be very strong. And, often enough, the rings end up thrown away into the sea, where they float for years. In the sea they are a hazard: animals eat them and starve, or become entangled in them. Sea-birds may get the rings caught around their necks; thus weighted down they are slow to take flight and become an easy catch for predators.

The answer to these problems under consideration by the congressional committee was S.1986, federal legislation requiring the rings to be made of degradable plastic. Seventeen states, most of them coastal, have laws or will soon be implementing laws to prohibit the use of nondegradable plastic rings and other carriers.

Al Manville, senior staff wildlife biologist for the Defenders of Wildlife, pressed for the legislation, saying that the United States could not afford to wait any longer to start doing something about the problem of plastic materials.

The Environmental Protection Agency, Illinois Tool Works and the Society of the Plastics Industry agreed that more research is needed, but opposed the passage of a bill until the best solution could be found. The United States Fish and Wildlife Service does not support the bill. Elizabeth Ebbert

West German Chancellor Helmut Kohl (CDU) has taken a personal interest in slowing the destruction of the world's tropical rainforests using debt relief for the developing countries involved. $\mathrm{He}$ and Environment Minister Klaus Töpfer (CDU) will press for international cooperation at the World Bank meeting in West Berlin in the autumn.

West Germany faces a number of problems in reducing its contribution to the greenhouse effect. Its only indigenous energy resource, coal, is the worst fossil fuel in terms of carbon dioxide release. Natural gas, the cleanest-burning fuel, is not found in West Germany, and nuclear power has not been a popular option, especially since the Chernobyl incident. The experts called before the Enquete Commission recommended energy conservation as the only practical way to reduce emissions.

Steven Dickman 